\title{
Oxidant metabolism in chronic obstructive pulmonary disease
}

\author{
A.W. Boots, G.R.M.M. Haenen, A. Bast
}

Oxidant metabolism in chronic obstructive pulmonary disease. A. W. Boots, G. R. M.M. Haenen, A. Bast. C) ERS Journals Ltd 2003.

ABSTRACT: The development and progression of chronic obstructive pulmonary disease (COPD) have been associated with increased oxidative stress or reduced antioxidant resources. Several indicators of oxidative stress, such as hydrogen peroxide exhalation, lipid peroxidation products and degraded proteins, are indeed elevated in COPD patients. As a result, the antioxidant capacity decreases in COPD patients.

The fall in antioxidant capacity of blood from COPD patients should not only be regarded as a reflection of the occurrence of oxidative stress but also as evidence that oxidative stress spreads out to the circulation and can therefore generate a systemic effect.

COPD is linked to weight loss and in particular to loss in fat-free mass by skeletal muscle wasting. This systemic effect can be mediated by both oxidative stress and oxidative stress-mediated processes like apoptosis and inflammation. Furthermore, COPD is a predisposition for lung cancer through several mechanisms including oxidative stress and oxidative stress-mediated processes such as inflammation and disruption of genomic integrity.

Current therapeutic interventions against the far-reaching consequences of the systemic oxidative stress in chronic obstructive pulmonary disease are not yet optimised. A diet designed to reduce chronic metabolic stress might form an effective therapeutic strategy in chronic obstructive pulmonary disease.

Eur Respir J 2003; 22: Suppl. 46, 14s-27s.
Dept of Pharmacology and Toxicology, Faculty of Medicine, University of Maastricht, Maastricht, The Netherlands.

Correspondence: A. Bast

Dept of Pharmacology and Toxicology

Faculty of Medicine

University of Maastricht

P.O. Box 616

6200 MD Maastricht

The Netherlands

Fax: 31433884149

E-mail: A.Bast@farmaco.unimaas.nl

Keywords: Chronic obstructive pulmonary disease

metabolism

oxidative stress

systemic

Received and accepted June 302003
Chronic obstructive pulmonary disease (COPD) is a heterogenous syndrome characterised by irreversible progressive airflow limitation [1-3]. It is expected that in 2020 COPD will become the third instead of the current fourth leading cause of death worldwide [4]. The most prominent risk factor for the clinical manifestations and progression of COPD is tobacco smoking. Although about $90 \%$ of all COPD patients are smokers, for unknown reasons only $20 \%$ of all smokers develop the disease $[5,6]$. Other risk factors include $\alpha_{1}{ }^{-}$ antitrypsin deficiency, air pollution, socioeconomic status and lower birth weight [5]. Recently, the development of COPD has also become associated with increased oxidative stress or reduced antioxidant resources [7, 8]. The purpose of this review is to evaluate the role of the oxidant-antioxidant imbalance in the development of COPD and of the oxidant metabolism in the systemic effects of COPD. Therapeutic approaches to alter this oxidant-antioxidant imbalance in COPD will also be discussed.

\section{Indicators of oxidative stress in chronic obstructive pulmonary disease}

\section{Hydrogen peroxide exhalation}

Hydrogen peroxide in exhaled breath directly reflects oxidant generation in the lung. Smokers as well as patients with COPD have higher levels of exhaled hydrogen peroxide $\left(\mathrm{H}_{2} \mathrm{O}_{2}\right)$ than exsmokers with COPD or nonsmokers [9, 10]. During acute exacerbations of COPD these $\mathrm{H}_{2} \mathrm{O}_{2}$-levels are even higher [11]. The source of the enhanced exhalation of $\mathrm{H}_{2} \mathrm{O}_{2}$ is unknown, but has been suggested to partly originate from the increased release of superoxide anion $\left(\mathrm{O}_{2}^{-}\right)$by the alveolar macrophages from smokers compared with that by the alveolar macrophages from nonsmokers [11, 12]. Moreover, the intracellular iron content of the alveolar macrophages from smokers is also increased compared with that of nonsmokers [13]. The presence of increased amounts of free iron in the airspaces of smokers may increase the generation of even more reactive oxygen species through the Fentonreaction [3, 14]. Additionally, the combination xanthine/ xanthine oxidase, capable of generating superoxide anion radical and $\mathrm{H}_{2} \mathrm{O}_{2}$, is increased in the bronchoalveolar lavage and plasma of COPD patients and smokers when compared with healthy subjects and nonsmokers respectively [15, 16]. Furthermore, it was shown that COPD patients performing strenuous exercise experience systemic oxidative stress, which can be inhibited by blocking xanthine oxidase [15].

\section{$N O^{\bullet}$ exhalation}

The gas $\mathrm{NO}^{\circ}$ is produced endogenously in the lung by NO synthase (NOS) that exists in both constitutive isoforms (cNOS) and an inducible isoform (iNOS) [17]. The latter can be induced by inflammatory stimuli in the lung and may therefore reflect airway inflammation. Consequently, exhaled $\mathrm{NO}^{*}$ levels are considered a marker for airway inflammation and an indirect measure of oxidative stress [17-19]. However, the results regarding the use of $\mathrm{NO}^{\circ}$ levels as a marker for COPD are inconclusive. Some studies report a higher level of exhaled $\mathrm{NO}^{\circ}[20,21]$ while others found either normal or even lower exhaled $\mathrm{NO}^{\circ}$ concentrations in stable COPD patients compared with control subjects $[22,23]$. These discrepancies 
may be due to the use of different methods of measurement or different criteria for patient selection. Furthermore, $\mathrm{NO}^{\bullet}$ itself is short-lived in vivo and can be easily transformed into $\mathrm{NO}_{\mathrm{x}}$ by its fast reaction with superoxide. It has been proposed that $\mathrm{NO}^{\circ}$ may form stable S-nitrothiols (RS-NOs) with low molecular weight thiols like glutathione or $N$-acetylcysteine in order to enhance its bioactivity [24-26]. In that way, RSNOs rather than $\mathrm{NO}^{\circ}$ are seen as the major products of NOS and inflammation. Studies regarding the RS-NOs levels in inflammatory airway diseases show increased levels in the exhaled breath condensate of COPD patients and smokers compared to nonsmokers and healthy control subjects [17].

\section{Lipid peroxidation products}

Reactive oxygen species (ROS) can trigger the peroxidation of polyunsaturated fatty acids in biological tissues resulting in the transformation of the fatty acids into lipid hydroperoxides. Lipid peroxides and lipid hydroperoxides can then interact with enzymatic or nonenzymatic antioxidants or decompose after reacting with metal ions or iron-containing proteins, forming hydrocarbon gases and unsaturated aldehydes as by-products [5].

Lipid peroxidation (LPO) products, measured as thiobarbituric acid-reacting substances, display higher levels in breath condensate and in lungs of stable COPD patients [27]. In addition, these LPO products negatively correlate with the lung function marker forced expiratory volume in one second (FEV1), suggesting that lipid peroxidation plays an important role in the decline of lung function [28]. In the plasma and lung lavages of healthy smokers the levels of LPO products are also increased. Furthermore, increased levels of LPO products are inversely correlated with the time expired from the last exposure to tobacco smoke and with the degree of small airway obstruction [5].

The specific endproduct of lipid peroxidation 4-hydroxy2,3-nonenal is capable of modifying cellular proteins. Airway epithelial cells and endothelial cells from smokers with airway obstruction display increased 4-hydroxy-2,3-nonenalmodified protein levels compared to nonsmokers or subjects without airway obstruction [29].

The hydrocarbon ethane is a by-product of the peroxidation of fatty acids such as 9,12,15-linolenic acid [18]. Patients with COPD display an increased level of exhaled ethane compared with control subjects. This increased level is negatively correlated with lung function, suggesting that lipid peroxidation is an important factor in the progression of COPD [18, 30]. Furthermore, ethane produced in several other organs than the lung, such as intestine, brain, kidney, liver, heart and testis, will be transported to the lung for elimination. Therefore, it is suggested that the systemic oxidative stress in smokers and COPD patients may contribute to the total exhaled ethane concentration [18, 31, 32].

Isoprostanes are made by ROS-mediated peroxidation of arachidonic acid which circulate in the plasma and can be excreted in the urine [33]. Isoprostanes also reflect systemic effects caused by ROS. Levels of 8-isoprostane are increased in exhaled air condensate in smokers and are negatively correlated with the severity of the airway obstruction [34]. In plasma, the levels of free and esterified $F_{2}$-isoprostanes are enhanced in smokers and decrease after smoking cessation for 2 weeks [35]. In urine, the levels of isoprostane $F_{2} \alpha$-III are elevated in COPD patients in comparison to healthy controls with the highest levels during exacerbations [36].

These studies show that oxidative stress, determined as products originated from LPO, is negatively associated with lung function.

\section{Inflammatory response}

Various studies have investigated the role of ROS in the generation of the inflammatory response occurring in both the central and the peripheral airways of COPD patients [3, 37]. A common feature of lung inflammation is the activation of epithelial cells and resident macrophages as well as the recruitment and activation of neutrophils [3]. Oxidants in cigarette smoke are capable of stimulating alveolar macrophages to release a number of mediators, some of which attract neutrophils and other inflammatory cells into the lungs [3, 38]. Increased numbers of both macrophages and neutrophils migrate into the lungs of smokers where they generate ROS via the reduced nicotinamide adenine dinucleotide phosphate (NADPH) oxidase system [38, 39]. Moreover, lungs of smokers with airway obstruction have more neutrophils than smokers without such an obstruction [40]. Peripheral blood neutrophils from both smokers and COPD patients during acute excerbations display an increased production of superoxide anion. In the latter group the production returned to its normal level when the patients were re-studied when clinically stable [41, 42]. The myeloperoxidase content of the neutrophils is positively associated with cigarette smoking, suggesting an increased production of oxidants like hypochlorous acid in smokers [43].

A relationship has been shown between circulating neutrophil numbers and the FEV1 [44, 45], suggesting an increased airflow limitation as a result of the ROS production of the increased number of neutrophils. Smokers that develop COPD have increased ROS release from these circulating neutrophils compared to smokers who do not develop the disease [46].

\section{Degradation of proteins}

Oxidative stress renders proteins more susceptible to proteolytic degradation by modifying amino acid chains, forming protein aggregates and cleaving peptide bonds [47]. During this process, some amino acid residues are converted to carbonyl residues that can be found systemically. Human plasma proteins are indeed modified to carbonyl-containing proteins with lost sulfhydryl groups after exposure to gasphase cigarette smoking [48]. Both the saturated and the unsaturated aldehydes present in cigarette smoke contribute to this modification of proteins [49, 50]. Additionally, exposure of human plasma to cigarette smoke in vitro also results in depletion of plasma protein sulfhydryls and elevation of the carbonyl protein levels [49]. Oxidative damage of proteins, and therefore the formation of carbonyl proteins, caused by cigarette smoke can be almost completely prevented by ascorbic acid and partially by glutathione [50, 51].

Plasma proteins can also be degraded through nitration and oxidation by reactive nitrogen species (RNS), the formation of which is stimulated by cigarette smoking [3]. Levels of oxidised proteins are significantly higher in smokers than in nonsmokers [52]. Smokers display higher levels of nitrated proteins, such as fibrinogen, transferrin, ceruloplasmin and plasminogen, compared to nonsmokers [52].

Furthermore, aldehydes present in cigarette smoke may react with the sulfhydryl- and amino- moieties of plasma proteins by a Michael addition reaction [53]. Conversion of the amino acid tyrosine into 3-nitrotyrosine and dityrosine can also be regarded as an indicator for free radical damage and protein damage [54]. Nitrotyrosine levels are elevated in plasma and epithelial lining fluid of smokers and negatively correlated with the FEV1 [55]. 
Finally, the activity of the elastase inhibitor alpha 1proteinase inhibitor (alpha 1PI) that plays an important role in preventing emphysema in COPD patients can be decreased by oxidising agents [56]. Oxidation of a critical methionine amino acid residue in alpha 1PI into methionine sulfoxide leads to a dramatic reduction of the inhibitory capacity of alpha 1 PI [57, 58]. Lung lavage of smokers display alpha 1 PI that contains only half of its normal activity and 4 moles of methionine sulfoxide per mole while the alpha 1 PI from lung washings of nonsmokers is fully active with only native methionine [56].

The evidence that oxidative stress plays an important role in the development and progression of COPD is summarised in fig. 1.

\section{Antioxidant capacity in chronic obstructive pulmonary disease}

The fall in antioxidant capacity of blood from smokers and COPD patients can not only be regarded as a reflection of the occurrence of oxidative stress but even more as evidence that oxidative stress spreads out to the circulation and can therefore generate a systemic effect [59].

Numerous studies have investigated the relationship between antioxidants and pulmonary function as well as respiratory diseases [60,61]. Analysis of this relationship is frequently performed using data on the dietary intake of antioxidants. Dietary intake data have for example been obtained from the American Nutrition Examination Survey (NHANES) or the Dutch Monitoring Project on Risk Factors for Chronic Diseases (MORGEN) study, a monitoring project on risk factors and health in the Netherlands.

In a subsample of NHANES I a lower dietary intake of vitamin $\mathrm{C}$ is directly related to lower values of FEV1. Moreover, the protective effect of vitamin $\mathrm{C}$ is even greater in asthma and bronchitis subjects [61]. Cigarette smokers display lower concentrations of serum vitamin $\mathrm{C}$ due to a decreased intake and an increased metabolism [62]. The latter phenomenon may result from the so-called protective utilisation of vitamin $\mathrm{C}$ under conditions of increased oxidative stress like smoking [63]. Data obtained in NHANES II display an inverse association between both dietary and serum vitamin $\mathrm{C}$ with chronic respiratory symptoms [64]. NHANES III shows that the jointly considered serum antioxidants vitamin $\mathrm{C}$, vitamin $\mathrm{E}$, selenium and $\beta$-carotene are associated with lung function [60]. Serum vitamin $\mathrm{C}$ has the same association with FEV1 among smokers, former smokers and nonsmokers. The association between lung function and serum selenium is stronger among current smokers compared to former or nonsmokers while both dietary and serum $\beta$-carotene levels display a weaker association among current smokers that even decreased further with increasing smoking dose [60].

So, the effect of the various serum antioxidants changes with the smoking status. This could be explained in two different ways: 1) some antioxidants may be more efficient than others in neutralising general versus cigarette smoke oxidants; and 2) the level of oxidant burden may have an effect on the efficiency of an antioxidant i.e. that some antioxidants display a stronger effect when the oxidant burden is high [60].

Analysis of the data obtained in the MORGEN study also reveals that a high intake of vitamin $C$ and $\beta$-carotene is associated with a higher FEV1 than a low intake of these antioxidants. Since no consistent associations are observed with respiratory symptoms, only a protective effect on lung function is suggested for the antioxidants vitamin $C$ and $\beta$ carotene [65]. The only confounding factor in the relationship between lung function and antioxidants is the educational level. A possible explanation may be that the educational level can be regarded as a healthy life style indicator, since subjects in this higher educational level are more likely to have a healthy lifestyle including a high intake of antioxidants [65].

A lack of association between dietary vitamin $E$ intake and lung function has been reported in several studies $[65,66]$. These results are not consistent with other studies that show a positive relationship between dietary intake of vitamin $\mathrm{E}$ and

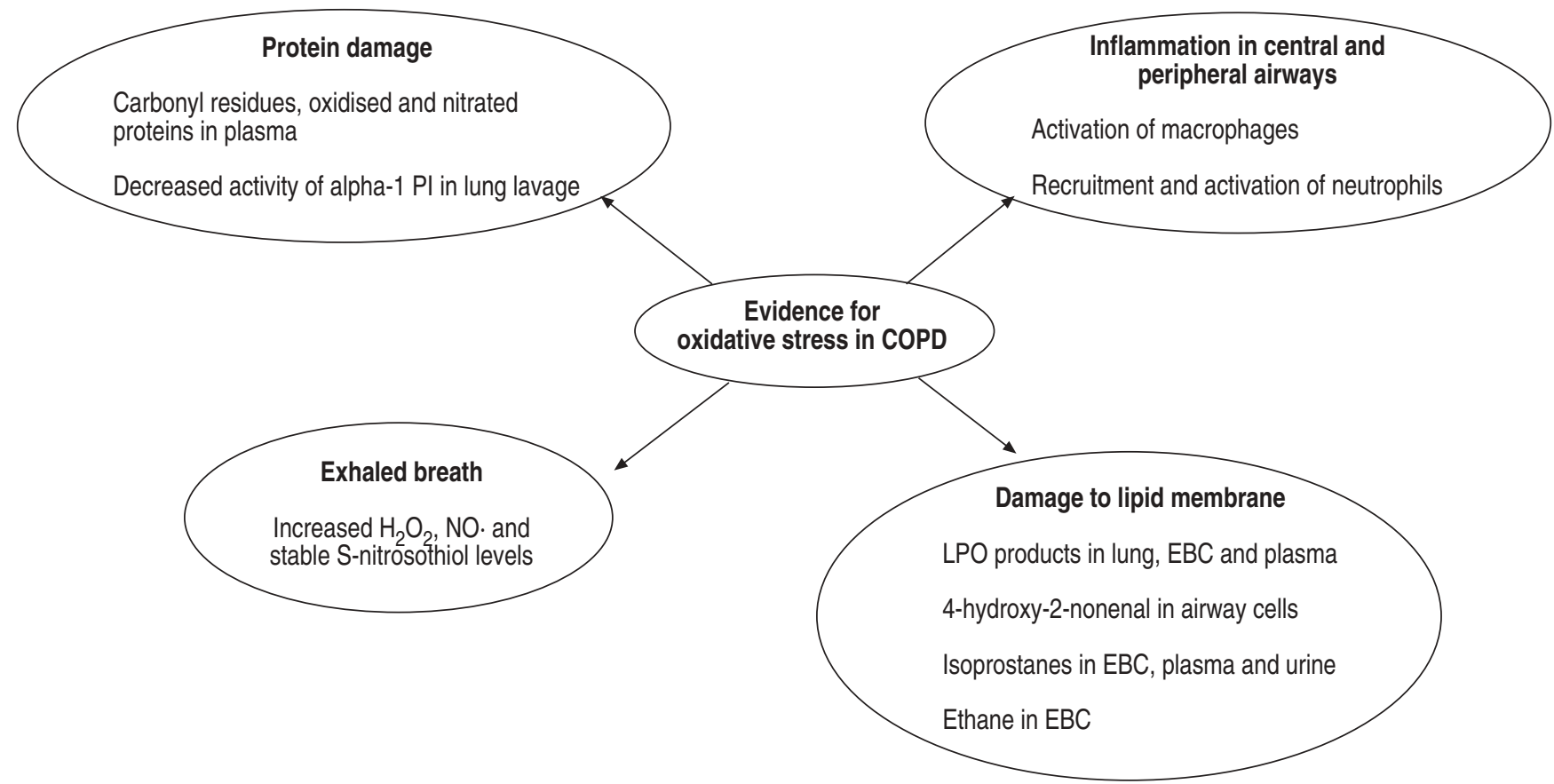

Fig. 1. - Evidence that links systemic oxidative stress to the development and progression of chronic obstructive pulmonary disease (COPD). LPO: lipid peroxidation; EBC: exhaled breath condensate; $\mathrm{H}_{2} \mathrm{O}_{2}$ : hydrogen peroxide; $\mathrm{NO}^{\circ}$ : nitric oxide. 
lung function [67] or between dietary intake of vitamin $\mathrm{E}$ and incidence of asthma [68].

Data from the MORGEN study also show an independent beneficial association of fruits $\left(>180 \mathrm{~g} \cdot \mathrm{day}^{-1}\right)$, whole grains $\left(>45 \mathrm{~g} \cdot \mathrm{day}^{-1}\right)$ and alcohol with COPD $\left(1-30 \mathrm{~g} \cdot \mathrm{day}^{-1}\right)$ [69]. In subjects with a positive intake of these foods, the FEV1 was significantly higher and the prevalence of COPD symptoms significantly lower. These beneficial effects are also found in nonsmokers, so confounding by smoking cannot explain the observed effect of diet on COPD totally. An association with COPD was not found for fish and vegetable intake.

The findings of the MORGEN study are consistent with others that have also shown an association between COPDrelated outcomes and fruit intake [70-74] but not with vegetable intake $[72,75]$. A possible explanation for the lack of association with vegetables could be that vegetables are usually boiled before consumption, which leads to loss of antioxidants like vitamin $\mathrm{C}$. The positive association between whole grain consumption and COPD can be explained as a result of the antioxidant components of whole grains like vitamin $\mathrm{E}$ and phenolic acids [76]. The effect of low alcohol consumption on COPD found in the MORGEN study is consistent with other studies [72, 77] and may be caused by the inhibitory effects of alcohol on inflammatory cells [78, 79]. Studies that have investigated the effect of fish intake on COPD are however not conclusive [64, 72, 74].

Finally, data from the MORGEN study show a beneficial association between the intake of three flavonoid subclasses, i.e. catechins, flavonols and flavones, and the FEV1 [80]. All three subclasses display anti-inflammatory and antioxidant activity and may therefore exert a positive effect on COPD. Indeed, catechin intake shows a strong positive association with all COPD symptoms but the intake of flavonols and flavones is only associated with cough. No beneficial effect of tea, the main dietary source of the catechins, on COPD is found indicating that the observed effect of the catechins is not causal. Instead the proposed effect of catechin may be caused by a substance not derived from tea, the intake of which is related to that of the catechins [80]. More direct studies have also linked a decreased antioxidant capacity of blood with tobacco smoking and COPD. Smokers display in their erythrocytes a decreased glutathione peroxidase activity [81]. Whole blood glutathione levels are decreased in smokers, but will return to normal values in 3 weeks after smoking cessation [82]. Cigarette smoke has also been associated with both a decreased serum antioxidant activity [39] and decreased plasma levels of the antioxidants ascorbate, vitamin E, $\beta$-carotene, uric acid and selenium [81, 83-87]. Vitamin E will be consumed only after complete depletion of ascorbic acid, suggesting that ascorbic acid acts as a general antioxidant reservoir and spares the use of the more specific vitamin $\mathrm{E}$ [83]. This reduction in plasma antioxidant levels in smokers is positively correlated with increased levels of protein carbonyls and lipid peroxides [48, 88]. Moreover, reduced plasma antioxidant levels appear to be associated with a family history of lung disease [89].

A decreased total antioxidant capacity also occurs in the plasma of COPD patients having an acute exacerbation [41] with a rise after the exacerbation when they were considered to be stable again [59]. However, their antioxidant levels did not return to the normal levels seen in clinically stable COPD patients who were studied at least 6 weeks after their last exacerbation. This decrease in total antioxidant capacity of blood is more pronounced in patients with a current smoking history than in former smokers [59]. This fall in antioxidant capacity correlates with the increased release of ROS from circulating neutrophils in COPD patients with exacerbations [41]. The decreased antioxidant capacity in plasma can have several causes, including depletion of protein sulfhydryls that become oxidised [59, 90].

Some smokers however display an increased level of antioxidants such as vitamin $\mathrm{E}$, vitamin $\mathrm{C}$ and glutathione [83, 91]. Additionally, increased levels of the antioxidant enzymes superoxide dismutase and catalase occur in circulating red blood cells from smokers [92]. This increased enzymatic antioxidant activity might be the result of the upregulation of protective antioxidant enzymes as an adaptive response triggered by the increased oxidative stress in COPD [3]. This adaptive reaction may serve as protection and, since not all smokers are capable of increasing their antioxidants, may also explain why not all smokers develop COPD [5].

\section{Body composition and chronic obstructive pulmonary disease}

Chronic conditions like COPD are generally accompanied with wasting of the body cell mass (BCM), which consists of both the actively metabolising (organs) and the contracting (muscles) tissue [93]. Since BCM is not directly measurable, weight loss and especially loss in fat-free mass (FFM) are considered as important markers of changes in BCM. Patients with advanced COPD often display weight loss, which is inversely correlated with the occurrence of exacerbations and can be seen as an independent predictor of outcome [94, 95]. The most important tissue in which weight loss occurs in COPD patients is the skeletal muscle, because wasting of the respiratory muscles implies an increased energy cost of breathing due to a loss of power and endurance [96, 97]. Other factors that display an adverse effect on the loss of FFM are peripheral muscle function, exercise capacity and health status [98-100].

Several factors influencing the loss in weight and in FFM in COPD patients are suggested including malnutrition, an imbalance in overall protein turnover and hormones involved in this process, tissue hypoxia and pulmonary inflammation $[93,97,99,101]$. There is also some evidence that links the wasting that occurs in COPD patients to both oxidative stress and oxidative stress-mediated processes, such as apoptosis, inflammation, disruption of the excitation-contraction coupling and atrophy [97, 102-104]. This effect of oxidative stress on skeletal muscle wasting in COPD is shown in figure 2.

\section{Effect and consequences of systemic oxidative stress}

Oxidative stress is regarded as a disbalance between formation of and protection against ROS and RNS and can result in damage to biomolecules.

Oxidative stress present in the systemic circulation of COPD patients can influence the skeletal muscle mass loss by stimulation of muscle proteolysis $[105,106]$. This is especially the case when the regulation of several important intracellular antioxidants like glutathione is disturbed [107].

Oxidative stress caused by overproduction of $\mathrm{NO}^{\circ}$ can be the result of an upregulated expression of iNOS in the muscle initiated by, for example, tissue hypoxia and systemic inflammation, processes that both occur in COPD [102, 108-110]. Skeletal muscles of COPD patients that suffer from weight loss indeed show such an upregulation of iNOS [111].

Furthermore, overproduction of $\mathrm{NO}^{\circ}$ may lead to oxidative stress and oxidative stress-mediated pathologies such as muscle wasting by impairment of antioxidant enzymes like superoxide dismutase or catalase [108]. Two commonly used models of skeletal muscle wasting, namely the hindlimb suspension and the chronic coronary occlusion, display an 


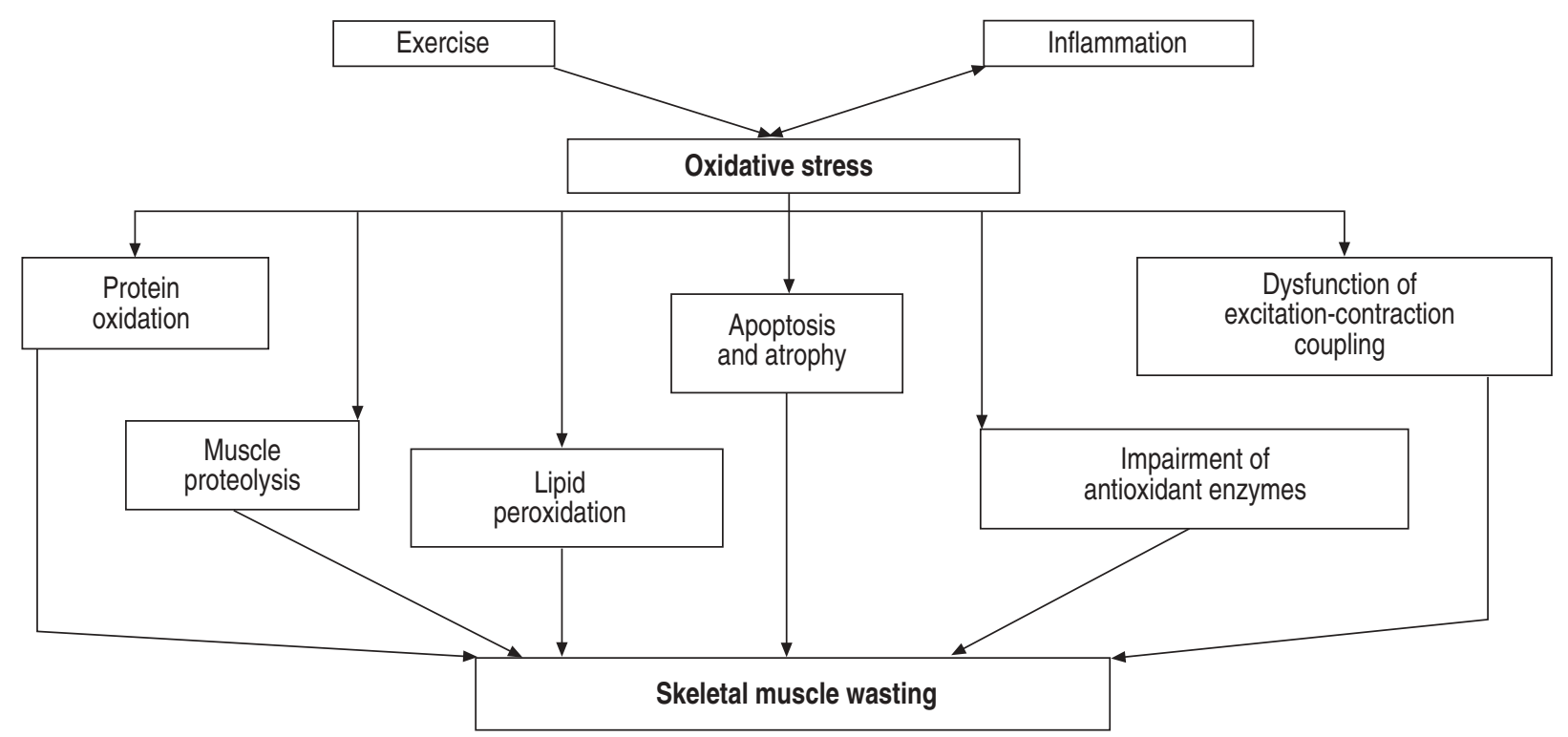

Fig. 2. - The effect of oxidative stress on skeletal muscle wasting in chronic obstructive pulmonary disease.

upregulation of iNOS, an increase in oxidative stress and a significant decrease in skeletal muscle antioxidant enzyme activity [112-115]. Muscle wasting pathologies such as cachexia also increase the production of ROS and RNS production and enhance the iNOS levels [116, 117]. Generation of ROS and RNS could lead to impairment of the antioxidant protection in skeletal muscles. A recent study using RNS challenge of skeletal muscle samples as a pathophysiological model showed that RNS are indeed capable of substantial downregulation of antioxidant enzymes in skeletal muscle. The degree of this down-regulation showed specificity for the various antioxidant enzymes and RNS donors, indicating that different antioxidants have different sensitivities to specific RNS donors [108].

Moreover, ROS can cause damage to lipids in biomembranes and to proteins both present in skeletal muscles [118]. Peroxidation of these lipids increases the permeability of membranes and in case of the mitochondrial inner membrane this can lead to leakage of ions, resulting in damage to the mitochondrial function and thereby reduction of the energy production. Reactions of ROS with proteins result in the formation of carbonyl groups on amino acid residues. Since this may change the structure and chemical properties of the proteins, their function will decline and they become more susceptible to proteinases or complete protein unfolding [119]. Both the lipid and the protein reactions with ROS may contribute to muscle wasting or muscle dysfunctioning.

Finally, oxidative stress is also an important factor in the ageing process that is characterised by changes in the skeletal muscles, including loss of muscle mass and function, atrophy of mainly type II muscle fibres and a decline of metabolic capacity $[103,120,121]$. It is therefore often suggested that a premature and/or accelerated ageing process contributes to the muscle wasting in COPD. However, since type I muscle fibres increase proportionally in elderly it can be suggested that the observed fibre-type redistribution in COPD, namely an increase of type II and a decrease in type I fibres, is not dependent of ageing [103]. Moreover, most studies in COPD patients make use of healthy age-matched control groups so that age-related changes have to be present in both groups, unless the reaction of patients to ageing is different from that of healthy controls [103]. These potential differences need to be further explored in order to elucidate the contribution of ageing to the muscle wasting seen in COPD patients.

Apoptosis. Apoptosis, an active process of cell death, is triggered by oxidative stress in experimental animals [122]. In mononucleated cells apoptosis will lead to cell death whereas in multinucleated cells like the myocytes cell atrophy will occur $[123,124]$. The unexplained weight loss in COPD patients is mainly caused by skeletal muscle atrophy, indicating that excessive apoptosis may occur in these patients [125]. Furthermore, several triggers of apoptosis like hypoxia, oxidative stress and systemic inflammation do exist in COPD patients $[126,127]$. A recent study in COPD patients with a low body weight indicates that increased apoptosis of skeletal muscles indeed occurs in these patients [102].

Exercise. In normal conditions skeletal muscles produce both ROS and RNS and they are associated with excitationcontraction [106, 128-130]. Exercise can cause an overproduction of these reactive species, leading to oxidative stress [128, 131]. Paradoxically, the disuse of muscles can also generate oxidative stress since a lower antioxidant-stimulating trigger consequently results in a lower antioxidant status [128, 132]. An occasional occurrence of exercise may in that case generate more reactive species than can be scavenged by the present antioxidants, resulting in a hypersensitivity for oxidative stress [133].

Furthermore, COPD patients display exercise-induced oxidation of blood glutathione [134] and increased lipid peroxidation products $[15,135]$. It is striking that both COPD patients and healthy subjects display the same degree of this exercise-induced glutathione oxidation. Since it is generally suggested that during exercise most ROS are generated in the oxidative metabolism in the mitochondria, it would be expected that the ROS production diminishes due to the reduced oxygen consumption that COPD patients display during maximal exercise. However, the observed enhanced oxidative stress in COPD patients during exercise can also be explained by disturbances in the mitochondrial respiratory chain, contribution of other sources besides the mitochondria to exercise-induced ROS generation and decreased antioxidant levels in COPD [130]. As explained below, excessive ROS can affect skeletal muscle functions in several ways. 
Excitation-contraction coupling. Skeletal muscle-contractility is affected by ROS in a dose- and time-dependent way. Low levels of the ROS generator xanthine oxidase cause a potentiation of muscle tension whereas higher levels result in a severe depression of contractility [136]. A comparable paradoxical role on muscle contractility is demonstrated for $\mathrm{NO}^{\circ}$ in various muscle preparations [137].

Various studies have indeed demonstrated that exposure to excessive oxidative stress causes contractile dysfunction of skeletal muscles [138-140]. Chronic exposure of skeletal muscle fibres to $\mathrm{H}_{2} \mathrm{O}_{2}$ reduced the force generation [138]. Increased lipid peroxidation, a result of ROS, in chronicallyloaded diaphragms is related positively with reduction in strength and with fatigability [139]. Noteworthy is the fact that in most studies the effect of oxidative stress could successfully be reversed by various types of antioxidants [141, 142], suggesting a possible mechanistic role for oxidative stress in the pathophysiology of muscle dysfunction [104].

ROS can affect skeletal muscle functions in various ways, for example by generating a blunted calcium-release from the sarcoplasmatic reticulum [143], by reducing the calcium sensitivity in skeletal muscles [138] or by causing enzymatic dysfunction within the glycolytic pathway, the citric acid cycle and the electron transport system leading to impairment of the cellular energetics [144, 145]. Taken together, it can be suggested that increased oxidative stress may impair the excitation-contraction coupling as well as the redox status, thereby accounting for at least a part of the skeletal muscle dysfunction seen in COPD [104].

Inflammation. Oxidative stress and inflammation are associated. There is evidence for the influence of oxidants on inflammation $[3,146]$ as well as for the role of inflammation in the induction of oxidative stress [147, 148].

On the one hand, the lung inflammatory response is initiated and mediated by increased levels of ROS that can activate the transcription of pro-inflammatory cytokine and chemokine genes as well as of transcription factors like nuclear factor kappa B $(\mathrm{NF}-\kappa \mathrm{B})$, upregulate adhesion molecules and increase the release of pro-inflammatory mediators [3, 146, 149-151].

On the other hand, several studies indicate that the inflammatory initiator and mediator tumour necrosis factor (TNF)- $\alpha$ is capable of stimulating oxidative stress in various cells and tissues $[147,148,152]$. Transfected animals expressing the inflammatory mediator TNF- $\alpha$ have higher levels of LPO products together with a stimulated NOS expression in their skeletal muscles. This indicates the induction of an oxidative pathway in these TNF- $\alpha$ animals [106, 153-155].

In COPD patients, inflammation indeed contributes to the observed weight loss in both a direct way, through for example inflammatory mediators like TNF- $\alpha$ and cytokines, and a more indirect way, through catabolic intermediary metabolism [156, 157].

Both oxidative stress and $\mathrm{NO}^{\bullet}$ overproduction are directly capable of mediating muscle wasting and skeletal muscle abnormalities, like a disturbed muscle contraction due to a decreased affinity of junD for the myosine creatinine phosphokinase (MCK) enhancer [106]. By binding to the MCK enhancer, junD stimulates MCK that is critical for differentiated skeletal muscle function since it delivers the energy required for muscle contraction by catalysing the adenosine triphosphate (ATP) formation from phosphocreatine [158].

Furthermore, increased circulating levels of TNF- $\alpha$ and interleukin- 6 as well as of their soluble receptors in subjects with a normal body mass index are associated with skeletal muscle loss, indicating an overall inverse relationship between skeletal muscle mass and these cytokines [97]. In differentiated myotubes, total protein content as well as adult myosin heavy chain content reduce in a time- and concentration-dependent manner after treatment with TNF- $\alpha$ [159]. Furthermore, TNF- $\alpha$ animals show a myosin depletion and a disrupted organisation in the skeletal muscle fibrils that can be prevented through treatment with various antioxidants like $\alpha$-tocopherol. These findings suggest that the TNF- $\alpha$ induced oxidative pathways and NOS stimulation contribute specifically to the development of muscle wasting [106].

Skeletal muscle loss in differentiated muscle cell lines can also be caused by TNF- $\alpha$ induced activation of NF- $\kappa \mathrm{B}$ [159]. Activated NF- $\kappa \mathrm{B}$ can inhibit the differentiation of skeletal muscles through suppression of the messenger ribonucleic acid (mRNA), and therefore of the protein levels, of transcription factor MyoD at post-transcriptional level [160]. Furthermore, TNF- $\alpha$ induced NF- $\kappa \mathrm{B}$ activation may inhibit the myogenic differentiation since it interferes with the expression of muscle proteins and the muscle creatine kinase activity in differentiating myoblasts $[93,161]$.

The influence of the more indirect catabolic intermediary metabolism can be seen in the increased nitrogen excretion, the excessive loss of nitrogen for FFM and the relationship between both a reduced FFM and a reduced skeletal muscle mass and the calculated protein catabolic rate [97]. Increased levels of circulating cytokines can contribute to this protein catabolic state.

As shown in several experimental animal and in vitro studies, both components of the energy balance, i.e. dietary intake and energy or substrate metabolism, can be influenced by inflammation [118]. Skeletal muscle proteins can become mobilised during inflammation in order to deliver the increased amount of amino acids necessary for acute phase protein synthesis. Increased levels of acute phase proteins in COPD patients are indeed correlated with an enhanced resting metabolic rate and FFM loss [157].

\section{Carcinogenesis and chronic obstructive pulmonary disease}

Since both lung cancer and pulmonary impairment are linked to tobacco smoke, it can be expected that these diseases frequently occur together $[162,163]$. Forty-nine per cent of lung cancer patients have COPD and as many as $12 \%$ of COPD patients between the age of 65-69 yrs die as a consequence of lung cancer [164, 165]. Most studies have found that, even after standardisation for the smoking habits, impaired pulmonary function increases the risk for lung cancer [166-169]. However, the strength of this relationship differs among the various studies from very weak [170] to quite strong [168]. When the relationship of pulmonary impairment with lung cancer is investigated by its histological type or tumour location, it displays a somewhat stronger association with squamous- or small-cell carcinoma than with adenocarcinoma [162, 171].

Furthermore, COPD is not only a risk factor for lung cancer, but also for death from lung cancer and death from any cause after matching for smoking habits [172]. However, a direct link between COPD and other primary forms of cancer has not been established [173].

The predisposition of COPD to lung cancer may occur by several mechanisms including impaired mucociliary clearance, genetic predisposition and oxidative stress-mediated processes like inflammation and stimulation of the carcinogenesis process [149, 167, 174, 175]. 


\section{Mucociliary clearance}

The predisposition of COPD to lung cancer may partly result from the impaired mucociliary clearance in smokers and even more in COPD patients $[172,176,177]$. In the more central airways, i.e. the sites where smoking-related cancers occur, microparticles are deposited. During the clearing process, the particles tend to assemble in areas that display the most impaired mucociliary clearance. These areas will, as a result of the pooling, be exposed longer to carcinogens from the smoke [178].

\section{Genetic predisposition}

A common denominator of the effects mediated by tobacco smoke could be pulmonary dysfunction, since preservation of other organs depends on a normal pulmonary function. Furthermore, ventilatory impairment is associated with mortality from COPD, ischaemic heart disease and overall mortality [179-186]. Impaired ventilatory function is more present in first-degree relatives of lung cancer patients and COPD patients than in control subjects or relatives of nonpulmonary patients $[174,187]$. Since this difference could not be ascribed to the tested genetic markers or to the adjustment factors like age, sex, alcohol and smoking, it is suggested that COPD and lung cancer share a common familial pathogenetic factor associated with ventilatory impairment [174, 187].

\section{Oxidative stress-mediated carcinogenesis}

As shown in figure 3, oxidative stress may be implicated in carcinogenesis via several pathways like inflammation and disruption of genomic integrity.

Inflammation. The risk for cancer in several organs like lungs, pancreas, esophagus and skin is increased in chronic inflammatory disorders [188]. Several epidemiological studies show that asthma, a disease characterised by persistent lung inflammation, elevates the risk of lung cancer [189-192]. In vitro, leucocytes can induce sister chromatid exchanges in hamster ovary cells [193]. Athymic mice injected with fibroblasts that were exposed to activated neutrophils, developed both benign and malign tumours whereas injection of control cells did not mediate tumour development [194]. Neutrophils can also induce deoxyribonucleic acid (DNA) base damage in naked DNA [195, 196] as well as in target cellular DNA [197]. Furthermore both neutrophils and macrophages are able to induce target cellular DNA strand breakage [198, 199].

The influence of inflammation on cancer may be mediated by inflammatory cell-derived ROS and RNS. Granulocytes and lymphocytes can generate at least four types of genotoxic or mutagenic products, namely $\mathrm{H}_{2} \mathrm{O}_{2}$, nitric oxide, malondialdehyde and 4-hydroxy-2,3-nonenal [155, 200-215]. $\mathrm{H}_{2} \mathrm{O}_{2}$ can function as a progenitor of ROS like the highly reactive hydroxyl radical [196, 197, 216]. The fact that the induction of ex vivo mutagenesis by alveolar macrophages is significantly lower than by neutrophils could be explained by the fact that neutrophils have a higher potential to increase the ROSgeneration after activation than macrophages [217-219].

Since lung inflammatory response can also be initiated and mediated by increased levels of ROS, it can be expected that in COPD patients the inflammation-induced risk of lung cancer will be further elevated.

Stimulation of cancer development. ROS can cause disruption of genomic integrity, a process required for neoplastic progression, in both a direct and an indirect way [220]. Directly they can introduce oncogenic mutations by causing DNA strand breaks or DNA adducts, whereas indirectly they may suppress genomic repair processes by modulating gene transcription and nuclear transcription factor activities [175, 220-225]. LPO-products like malondialdehyde and 4-hydroxy2,3-nonenal can also directly react with DNA bases, forming exocyclic DNA adducts like propano- and etheno( $(\varepsilon)-$ DNA adducts [175]. Moreover, ROS can contribute to the formation of DNA adducts by activating polycyclic aromatic hydrocarbons (PAH's) to a DNA binding metabolite [226, 227]. The mainly tobacco-derived PAH benzo-a-pyrene $(\mathrm{B}[43] \mathrm{P})$ for example can be activated through a oneelectron oxidation [228]. The generated $\mathrm{B}[\mathrm{a}] \mathrm{P}^{+}$-radical cation predominantly forms labile guanine or adenine DNA adducts, but can also induce some stable DNA adducts [229, 230]. Furthermore, the cation can also function as an intermediate metabolite which upon auto-oxidation ultimately results in the formation of reactive quinones [231].

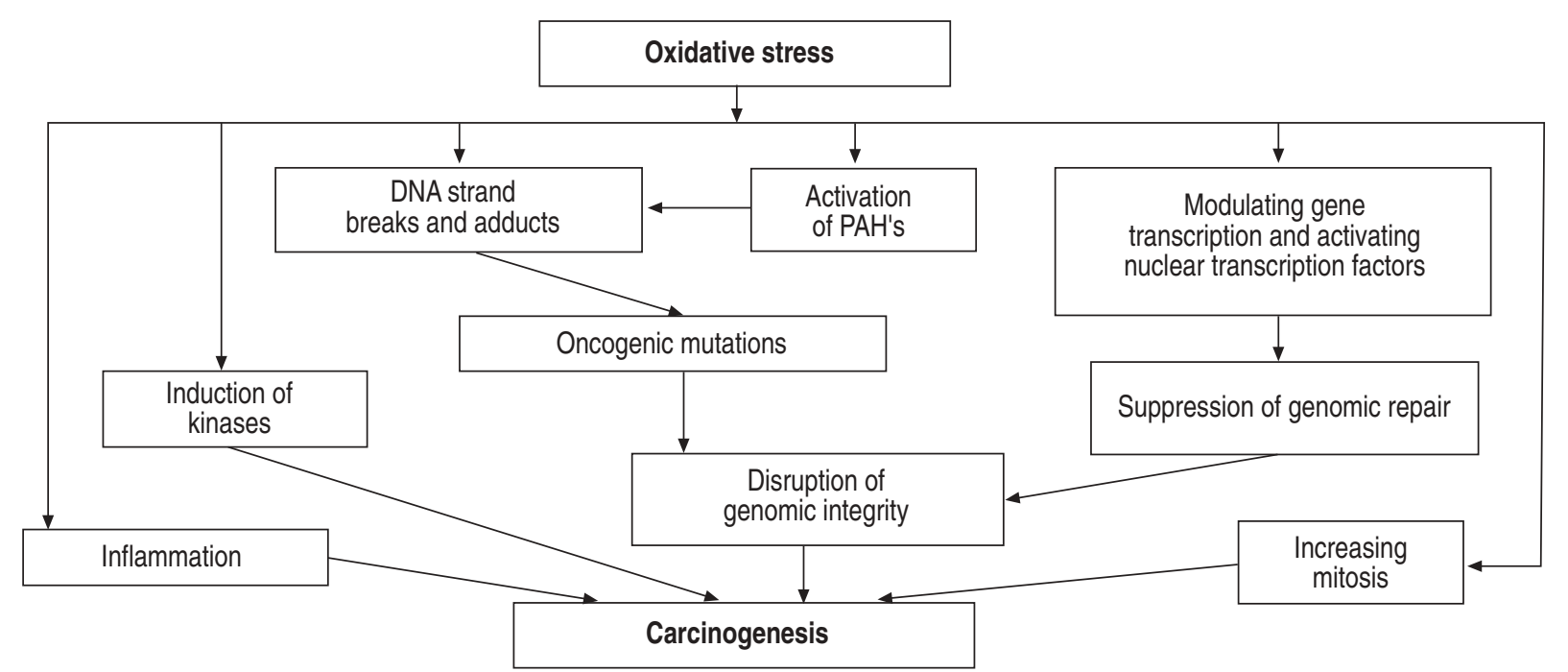

Fig. 3.-Oxidative-stress mediated effects on carcinogenesis in chronic obstructive pulmonary disease. DNA: deoxyribonucleic acid; PAH: polycyclic aromatic hydrocarbons. 
Finally, ROS can also contribute to carcinogenesis by modifying intracellular proteins, inducing mitogen-activated protein kinases and increasing mitosis [220, 232, 233]. However, ROS are also capable of inducing permanent growth arrest and activating several caspases as well as the release of cytochrome $\mathrm{c}$ in order to induce cell death by apoptosis [232-234].

\section{Conclusion}

It is evident that local (pulmonary) and systemic aberrant metabolism of oxidants occur in COPD patients. The resulting chronic metabolic stress may have far-reaching consequences ranging from exacerbations to muscle wasting and carcinogenesis. Therapeutic intervention should therefore include three approaches: 1) prevention of oxidant formation, 2) inhibition of oxidant effects and 3) repair of oxidantmediated damage.

Adequate anti-inflammatory pharmacotherapy may prevent the formation of oxidant generation. Optimal treatment to diminish the neutrophilic inflammation in COPD has not yet been achieved with either classical or new drugs such as corticosteroids, chemokine inhibitors, leukotriene $\mathrm{B}_{4}$ inhibitors, adhesion molecule inhibitors, phosphodiesterase inhibitors or neutrophil function blockers [235].

Attempts to attenuate other possible pathways for ROS generation have only been explored in a limited way. An interesting recent finding is the inhibition of ROS-generating enzyme xanthine oxidase by allopurinol in COPD [15].

Antioxidants might be used to combat the oxidant effects. The antioxidant $\mathrm{N}$-acetylcysteine has been shown to reduce acute exacerbations in COPD [236]. Intervention studies with other antioxidants have not been performed. It is now known that enzymatic and nonenzymatic antioxidants form an intricate network that functions as a shield against ROS [237]. Knowledge on the functioning of this network is slowly emerging. It appears that the network differs between various tissues. This becomes clear when the composition of two extracellular fluids, i.e. the pulmonary epithelial lining fluid and blood plasma, are compared [238]. Rational supplementation in this antioxidant network is only possible when the changes that occur as a result of COPD are known. Until now only general dietary intake of antioxidants has been associated with improvement of lung function. It might be anticipated that a more specific supplementation may result in better results.

Finally, it might be speculated that enhancement of repair of pulmonary or systemic oxidative damage may lead to new therapeutic avenues. An example of this approach is the stimulated repair of the oxidised $\alpha_{1}$-antiprotease. It has been shown that it is possible to reduce oxidised methionine in oxidatively damaged $\alpha_{1}$-antiprotease thus restoring its activity [239].

The chronic and systemic oxidant burden in chronic obstructive pulmonary disease warrants a continuous elevated antioxidant level to circumvent oxidative damage. The diet forms the major source of antioxidants in the body. The joint activity of the antioxidant ingredients in the diet is probably superior to the classical pharmacotherapeutic antioxidant action of individual compounds, which act in isolation. Moreover, the chronic and systemic character of chronic obstructive pulmonary disease asks for a nutritional rather than a pharmacological intervention. Optimising the antioxidant content of the diet might therefore be utilised to avert or treat chronic metabolic stress in chronic obstructive pulmonary disease.

\section{References}

1. Agusti AG. Systemic effects of chronic obstructive pulmonary disease. Novartis Found Symp 2001; 234: 242-254.

2. Rennard SI. Overview of causes of COPD. New understanding of pathogenesis and mechanisms can guide future therapy. Postgrad Med 2002; 111: 28-30, 33-34, 37-38.

3. MacNee W. Oxidative stress and lung inflammation in airways disease. Eur J Pharmacol 2001; 429: 195-207.

4. Viegi G, Scognamiglio A, Baldacci S, Pistelli F, Carrozzi L. Epidemiology of chronic obstructive pulmonary disease (COPD). Respiration 2001; 68: 4-19.

5. Repine JE, Bast A, Lankhorst I. Oxidative stress in chronic obstructive pulmonary disease. Oxidative Stress Study Group. Am J Respir Crit Care Med 1997; 156: 341-357.

6. Snider GL. Chronic obstructive pulmonary disease: risk factors, pathophysiology and pathogenesis. Annu Rev Med 1989; 40: 411-429.

7. Heffner JE, Repine JE. Pulmonary strategies of antioxidant defense. Am Rev Respir Dis 1989; 140: 531-554.

8. White CW, Repine JE. Pulmonary antioxidant defense mechanisms. Exp Lung Res 1985; 8: 81-96.

9. Nowak D, Antczak A, Krol M, et al. Increased content of hydrogen peroxide in the expired breath of cigarette smokers. Eur Respir J 1996; 9: 652-657.

10. Macnee W, Rahman I. Oxidants and antioxidants as therapeutic targets in chronic obstructive pulmonary disease. Am J Respir Crit Care Med 1999; 160: S58-65.

11. Dekhuijzen PN, Aben KK, Dekker I, et al. Increased exhalation of hydrogen peroxide in patients with stable and unstable chronic obstructive pulmonary disease. Am J Respir Crit Care Med 1996; 154: 813-816.

12. Hoidal JR, Fox RB, LeMarbe PA, Perri R, Repine JE. Altered oxidative metabolic responses in vitro of alveolar macrophages from asymptomatic cigarette smokers. Am Rev Respir Dis 1981; 123: 85-89.

13. Thompson AB, Bohling T, Heires A, Linder J, Rennard SI. Lower respiratory tract iron burden is increased in association with cigarette smoking. J Lab Clin Med 1991; 117: 493499.

14. Lapenna D, de Gioia S, Mezzetti A, et al. Cigarette smoke, ferritin, and lipid peroxidation. Am J Respir Crit Care Med 1995; 151: 431-435.

15. Heunks LM, Vina J, van Herwaarden CL, Folgering HT, Gimeno A, Dekhuijzen PN. Xanthine oxidase is involved in exercise-induced oxidative stress in chronic obstructive pulmonary disease. Am J Physiol 1999; 277: R1697-1704.

16. Pinamonti S, Muzzoli M, Chicca MC, et al. Xanthine oxidase activity in bronchoalveolar lavage fluid from patients with chronic obstructive pulmonary disease. Free Radic Biol Med 1996; 21: 147-155.

17. Corradi M, Montuschi P, Donnelly LE, Pesci A, Kharitonov SA, Barnes PJ. Increased nitrosothiols in exhaled breath condensate in inflammatory airway diseases. Am $\mathrm{J}$ Respir Crit Care Med 2001; 163: 854-858.

18. Paredi P, Kharitonov SA, Leak D, Ward S, Cramer D, Barnes PJ. Exhaled ethane, a marker of lipid peroxidation, is elevated in chronic obstructive pulmonary disease. Am J Respir Crit Care Med 2000; 162: 369-373.

19. Alving K, Weitzberg E, Lundberg JM. Increased amount of nitric oxide in exhaled air of asthmatics. Eur Respir $J$ 1993; 6: 1368-1370.

20. Delen FM, Sippel JM, Osborne ML, Law S, Thukkani N, Holden WE. Increased exhaled nitric oxide in chronic bronchitis: comparison with asthma and COPD. Chest 2000; 117: 695-701.

21. Maziak W, Loukides S, Culpitt S, Sullivan P, Kharitonov SA, Barnes PJ. Exhaled nitric oxide in chronic obstructive pulmonary disease. Am J Respir Crit Care Med 1998; 157: 998-1002.

22. Rutgers SR, van der Mark TW, Coers W, et al. Markers of nitric oxide metabolism in sputum and exhaled air are not 
increased in chronic obstructive pulmonary disease. Thorax 1999; 54: 576-580.

23. Clini E, Bianchi L, Pagani M, Ambrosino N. Endogenous nitric oxide in patients with stable COPD: correlates with severity of disease. Thorax 1998; 53: 881-883.

24. Gaston B, Reilly J, Drazen JM, et al. Endogenous nitrogen oxides and bronchodilator S-nitrosothiols in human airways. Proc Natl Acad Sci USA 1993; 90: 10957-10961.

25. Jia L, Bonaventura C, Bonaventura J, Stamler JS. Snitrosohaemoglobin: a dynamic activity of blood involved in vascular control. Nature 1996; 380: 221-226.

26. Mathews WR, Kerr SW. Biological activity of S-nitrosothiols: the role of nitric oxide. J Pharmacol Exp Ther 1993; 267: 1529-1537.

27. Nowak D, Kasielski M, Antczak A, Pietras T, Bialasiewicz $P$. Increased content of thiobarbituric acid-reactive substances and hydrogen peroxide in the expired breath condensate of patients with stable chronic obstructive pulmonary disease: no significant effect of cigarette smoking. Respir Med 1999; 93: 389-396.

28. Tsukagoshi H, Shimizu Y, Iwamae S, et al. Evidence of oxidative stress in asthma and COPD: potential inhibitory effect of theophylline. Respir Med 2000; 94: 584-588.

29. Rahman I, van Schadewijk AAM, Crowther AJL, et al. 4-Hydroxy-2-nonenal, a specific lipid peroxidation product, is elevated in lungs of patients with chronic obstructive pulmonary disease. Am J Respir Crit Care Med 2002; 166: 490-495.

30. Habib MP, Tank LJ, Lane LC, Garewal HS. Effect of vitamin $\mathrm{E}$ on exhaled ethane in cigarette smokers. Chest 1999; 115: 684-690.

31. Habib MP, Katz MA. Source of ethane in expirate of rats ventilated with 100\% oxygen. J Appl Physiol 1989; 66: 12681272.

32. Habib MP, Clements NC, Garewal HS. Cigarette smoking and ethane exhalation in humans. Am J Respir Crit Care Med 1995; 151: 1368-1372.

33. Morrow JD, Roberts LJ. The isoprostanes: unique bioactive products of lipid peroxidation. Prog Lipid Res 1997; 36: 1-21.

34. Montuschi P, Kharitonov SA, Ciabattoni G, et al. Exhaled 8-isoprostane as a new non-invasive biomarker of oxidative stress in cystic fibrosis. Thorax 2000; 55: 205-209.

35. Morrow JD, Frei B, Longmire AW, et al. Increase in circulating products of lipid peroxidation (F2-isoprostanes) in smokers. Smoking as a cause of oxidative damage. $N$ Engl J Med 1995; 332: 1198-1203.

36. Pratico D, Basili S, Vieri M, Cordova C, Violi F, Fitzgerald GA. Chronic obstructive pulmonary disease is associated with an increase in urinary levels of isoprostane F2alpha-III, an index of oxidant stress. Am J Respir Crit Care Med 1998; 158: 1709-1714.

37. Saetta M, Turato G, Maestrelli P, Mapp CE, Fabbri LM. Cellular and structural bases of chronic obstructive pulmonary disease. Am J Respir Crit Care Med 2001; 163: 1304-1309.

38. Rennard SI. Inflammation and repair processes in chronic obstructive pulmonary disease. Am J Respir Crit Care Med 1999; 160: S12-16.

39. Rahman I, MacNee W. Oxidant/antioxidant imbalance in smokers and chronic obstructive pulmonary disease. Thorax 1996; 51: 348-350.

40. Bosken $\mathrm{CH}$, Hards J, Gatter K, Hogg JC. Characterization of the inflammatory reaction in the peripheral airways of cigarette smokers using immunocytochemistry. Am Rev Respir Dis 1992; 145: 911-917.

41. Rahman I, Morrison D, Donaldson K, MacNee W. Systemic oxidative stress in asthma, COPD, and smokers. Am J Respir Crit Care Med 1996; 154: 1055-1060.

42. Muns G, Rubinstein I, Singer P, Bergmann KC. Phagocytosis and oxidative burst of blood phagocytes in chronic obstructive airway disease. J Otolaryngol 1995; 24: 105-110.

43. Aaron SD, Angel JB, Lunau M, et al. Granulocyte inflammatory markers and airway infection during acute exacerbation of chronic obstructive pulmonary disease. $\mathrm{Am}$ J Respir Crit Care Med 2001; 163: 349-355.

44. Chan-Yeung M, Dybuncio A. Leucocyte count, smoking and lung function. American Journal of Medicine 1984; 76: $31-37$.

45. van Antwerpen VL, Theron AJ, Richards GA, et al. Vitamin E, pulmonary functions, and phagocyte-mediated oxidative stress in smokers and nonsmokers. Free Radic Biol Med 1995; 18: 935-941.

46. Noguera A, Busquets X, Sauleda J, Villaverde JM, MacNee $\mathrm{W}$, Agusti AG. Expression of adhesion molecules and $\mathrm{G}$ proteins in circulating neutrophils in chronic obstructive pulmonary disease. Am J Respir Crit Care Med 1998; 158: $1664-1668$.

47. Stadtman ER. Metal ion-catalyzed oxidation of proteins: biochemical mechanism and biological consequences. Free Radic Biol Med 1990; 9: 315-325.

48. Reznick AZ, Cross CE, Hu ML, et al. Modification of plasma proteins by cigarette smoke as measured by protein carbonyl formation. Biochem J 1992; 286: 607-611.

49. Nagler R, Lischinsky S, Diamond E, Drigues N, Klein I, Reznick AZ. Effect of cigarette smoke on salivary proteins and enzyme activities. Arch Biochem Biophys 2000; 379: 229-236.

50. $\mathrm{O}^{\prime}$ Neill CA, Halliwell B, van der Vliet A, et al. Aldehydeinduced protein modifications in human plasma: protection by glutathione and dihydrolipoic acid. J Lab Clin Med 1994; 124: $359-370$.

51. Panda K, Chattopadhyay R, Chattopadhyay D, Chatterjee IB. Cigarette smoke-induced protein oxidation and proteolysis is exclusively caused by its tar phase: prevention by vitamin C. Toxicol Lett 2001; 123: 21-32.

52. Pignatelli B, Li CQ, Boffetta $\mathrm{P}$, et al. Nitrated and oxidized plasma proteins in smokers and lung cancer patients. Cancer Res 2001; 61: 778-784.

53. Eiserich JP, van der Vliet A, Handelman GJ, Halliwell B, Cross CE. Dietary antioxidants and cigarette smoke-induced biomolecular damage: a complex interaction. Am J Clin Nutr 1995; 62: 1490s-1500s.

54. Petruzzelli S, Puntoni R, Mimotti P, et al. Plasma 3nitrotyrosine in cigarette smokers. Am J Respir Crit Care Med 1997; 156: 1902-1907.

55. Ichinose M, Sugiura H, Yamagata S, Koarai A, Shirato K. Increase in reactive nitrogen species production in chronic obstructive pulmonary disease airways. Am J Respir Crit Care Med 2000; 162: 701-706.

56. Janoff A, Carp H, Laurent P, Raju L. The role of oxidative processes in emphysema. Am Rev Respir Dis 1983; 127: S31-38.

57. Bieth JG. The antielastase screen of the lower respiratory tract. Eur J Respir Dis Suppl 1985; 139: 57-61.

58. Evans MD, Pryor WA. Damage to human alpha-1proteinase inhibitor by aqueous cigarette tar extracts and the formation of methionine sulfoxide. Chem Res Toxicol 1992; 5: 654-660.

59. Rahman I, Skwarska E, MacNee W. Attenuation of oxidant/antioxidant imbalance during treatment of exacerbations of chronic obstructive pulmonary disease. Thorax 1997; 52: 565-568.

60. Hu G, Cassano PA. Antioxidant nutrients and pulmonary function: the Third National Health and Nutrition Examination Survey (NHANES III). Am J Epidemiol 2000; 151: 975-981.

61. Schwartz J, Weiss ST. Relationship between dietary vitamin $\mathrm{C}$ intake and pulmonary function in the First National Health and Nutrition Examination Survey (NHANES I). Am J Clin Nutr 1994; 59: 110-114.

62. Schectman G, Byrd JC, Gruchow HW. The influence of smoking on vitamin $\mathrm{C}$ status in adults. Am J Public Health 1989; 79: 158-162.

63. Bendich A, Machlin LJ, Scandurra O. The anti-oxidant role of vitamin C. Free Radic Biol Med 1986; 2: 419-444. 
64. Schwartz J, Weiss ST. Dietary factors and their relation to respiratory symptoms. The Second National Health and Nutrition Examination Survey. Am J Epidemiol 1990; 132: $67-76$.

65. Grievink L, Smit HA, Ocke MC, van 't Veer P, Kromhout D. Dietary intake of antioxidant (pro)-vitamins, respiratory symptoms and pulmonary function: the MORGEN study. Thorax 1998; 53: 166-171.

66. Britton JR, Pavord ID, Richards KA, et al. Dietary antioxidant vitamin intake and lung function in the general population. Am J Respir Crit Care Med 1995; 151: 1383-1387.

67. Dow L, Tracey M, Villar A, et al. Does dietary intake of vitamins $\mathrm{C}$ and $\mathrm{E}$ influence lung function in older people? $\mathrm{Am}$ J Respir Crit Care Med 1996; 154: 1401-1404.

68. Troisi RJ, Willett WC, Weiss ST, Trichopoulos D, Rosner B, Speizer FE. A prospective study of diet and adult-onset asthma. Am J Respir Crit Care Med 1995; 151: 1401-1408.

69. Tabak C, Smit HA, Heederik D, Ocke MC, Kromhout D. Diet and chronic obstructive pulmonary disease: independent beneficial effects of fruits, whole grains, and alcohol (the MORGEN study). Clin Exp Allergy 2001; 31: 747-755.

70. Carey IM, Strachan DP, Cook DG. Effects of changes in fresh fruit consumption on ventilatory function in healthy British adults. Am J Respir Crit Care Med 1998; 158: 728-733.

71. Cook DG, Carey IM, Whincup PH, et al. Effect of fresh fruit consumption on lung function and wheeze in children. Thorax 1997; 52: 628-633.

72. Miedema I, Feskens EJ, Heederik D, Kromhout D. Dietary determinants of long-term incidence of chronic nonspecific lung diseases. The Zutphen Study. Am J Epidemiol 1993; 138: 37-45.

73. Strachan DP, Cox BD, Erzinclioglu SW, Walters DE, Whichelow MJ. Ventilatory function and winter fresh fruit consumption in a random sample of British adults. Thorax 1991; 46: 624-629.

74. Tabak C, Feskens EJ, Heederik D, Kromhout D, Menotti A, Blackburn HW. Fruit and fish consumption: a possible explanation for population differences in COPD mortality (The Seven Countries Study). Eur J Clin Nutr 1998; 52: 819-825.

75. LaVecchia C, Decarli A, Pagano R. Vegetable consumption and risk of chronic disease. Epidemiololgy 1998; 9: 208-210.

76. Thompson LU. Antioxidants and hormone-mediated health benefits of whole grains. Crit Rev Food Sci Nutr 1994; 34: 473-497.

77. Pratt PC, Volmer RT. The beneficial effect of alcohol consumption on the prevalence and extent of centrilobular emphysema; a retrospective autopsy analysis. Chest 1984; 85: $372-377$.

78. Maxwell WJ, Keating JJ, Hogan FP, Kennedy NP, Keeling PW. Prostaglandin E2 and leukotriene B4 synthesis by peripheral leucocytes in alcoholics. Gut 1989; 30: 1270-1274.

79. Rettori V, McCann SM. Role of nitric oxide and alcohol on gonadotropin release in vitro and in vivo. Ann N Y Acad Sci 1998; 840: 185-193.

80. Tabak C, Arts IC, Smit HA, Heederik D, Kromhout D. Chronic obstructive pulmonary disease and intake of catechins, flavonols, and flavones: the MORGEN Study. Am J Respir Crit Care Med 2001; 164: 61-64.

81. Duthie GG, Authur JR, James WP. Effects of smoking and vitamin E on blood antioxidant status. Am J Clin Nutr 1991; 53: 1061-1063.

82. Lane JD, Opara EC, Rose JE, Behm F. Quitting smoking raises whole blood glutathione. Physiol Behav 1996; 60: 1379-1381.

83. Mezzetti A, Lapenna D, Pierdomenico SD, et al. Vitamins E, $\mathrm{C}$ and lipid peroxidation in plasma and arterial tissue of smokers and non-smokers. Atherosclerosis 1995; 112: 91-99.

84. Petruzzelli S, Hietanen E, Bartsch H, et al. Pulmonary lipid peroxidation in cigarette smokers and lung cancer patients. Chest 1990; 98: 930-935.
85. Bridges AB, Scott NA, Parry GJ, Belch JJ. Age, sex, cigarette smoking and indices of free radical activity in healthy humans. Eur J Med 1993; 2: 205-208.

86. Chow CK, Thacker RR, Changchit C, et al. Lower levels of vitamin $\mathrm{C}$ and carotenes in plasma of cigarette smokers. $\mathrm{J} \mathrm{Am}$ Coll Nutr 1986; 5: 305-312.

87. van Antwerpen L, Theron AJ, Myer MS, et al. Cigarette smoke-mediated oxidant stress, phagocytes, vitamin C, vitamin E, and tissue injury. Ann N Y Acad Sci 1993; 686: 53-65.

88. Frei B, Forte TM, Ames BN, Cross CE. Gas phase oxidants of cigarette smoke induce lipid peroxidation and changes in lipoprotein properties in human blood plasma. Protective effects of ascorbic acid. Biochem J 1991; 277: 133-138.

89. Taylor JC, Madison R, Kosinska D. Is antioxidant deficiency related to chronic obstructive pulmonary disease? Am Rev Respir Dis 1986; 134: 285-289.

90. Cross CE, O'Neill CA, Reznick AZ, et al. Cigarette smoke oxidation of human plasma constituents. Ann N Y Acad Sci 1993; 686: 72-90.

91. Kathawalla SA, Comhair S, Erzurum SC. Correlation of secondary glutathione peroxidase and glutathione in airways of smoking individuals (abstract). Am J Respir Crit Care Med 1996; 153: A812.

92. Toth KM, Berger EM, Beehler CJ, Repine JE. Erythrocytes from cigarette smokers contain more glutathione and catalase and protect endothelial cells from hydrogen peroxide better than do erythrocytes from nonsmokers. $\mathrm{Am}$ Rev Respir Dis 1986; 134: 281-284.

93. Wouters EFM, Creutzberg EC, Schols AMWJ. Systemic effects in COPD. Chest 2002; 121: 127s-130s.

94. Gray Donald K, Gibbons L, Shapiro SH, Macklem PT, Martin JG. Nutritional status and mortality in chronic obstructive pulmonary disease. Am J Respir Crit Care Med 1996; 153: 961-966.

95. Landbo C, Prescott E, Lange P, Vestbo J, Almdal TP. Prognostic value of nutritional status in chronic obstructive pulmonary disease. Am J Respir Crit Care Med 1999; 160: $1856-1861$.

96. Nishimura Y, Tsutsumi M, Nakata H, Tsunenari T, Maeda H, Yokoyama M. Relationship between respiratory muscle strength and lean body mass in men with COPD. Chest 1995; 107: 1232-1236.

97. Eid AA, Ionescu AA, Nixon LS, et al. Inflammatory response and body composition in chronic obstructive pulmonary disease. Am J Respir Crit Care Med 2001; 164: 1414-1418.

98. Baarends EM, Schols AM, Mostert R, Wouters EF. Peak exercise response in relation to tissue depletion in patients with chronic obstructive pulmonary disease. Eur Respir $J$ 1997; 10: 2807-2813.

99. Engelen MP, Schols AM, Does JD, Wouters EF. Skeletal muscle weakness is associated with wasting of extremity fatfree mass but not with airflow obstruction in patients with chronic obstructive pulmonary disease. Am J Clin Nutr 2000; 71: 733-738

100. Palange P, Forte S, Felli A, Galassetti P, Serra P, Carlone S. Nutritional state and exercise tolerance in patients with COPD. Chest 1995; 107: 1206-1212.

101. Jenkins RC, Ross RJ. Growth hormone therapy for protein catabolism. QJM 1996; 89: 813-819.

102. Agusti AGN, Cari PG, Sauleda J, Busquets X. Weight loss in chronic obstructive pulmonary disease. Mechanisms and implications. Pulm Pharmacol Therapeut 2002; 15: 425-432.

103. Franssen FME, Wouters EFM, Schols AMWJ. The contribution of starvation, deconditioning and ageing to the observed alterations in peripheral skeletal muscle in chronic organ diseases. Clin Nutr 2002; 21: 1-14.

104. Mattson JP, Murray DM, Poole DC. Lipid peroxidation in the skeletal muscle of hamsters with emphysema. Pathophysiology 2002; 8: 215-221.

105. Mitch WE, Goldberg AL. Mechanisms of muscle wasting. The role of the ubiquitin-proteasome pathway. $N$ Engl J Med 1996; 335: 1897-1905. 
106. Buck M, Chojkier M. Muscle wasting and dedifferentiation induced by oxidative stress in a murine model of cachexia is prevented by inhibitors of nitric oxide synthesis and antioxidants. EMBO J 1996; 15: 1753-1765.

107. Rabinovich RA, Ardite E, Troosters T, et al. Reduced muscle redox capacity after endurance training in patients with chronic obstructive pulmonary disease. Am J Respir Crit Care Med 2001; 164: 1114-1118.

108. Lawler JM, Song W. Specificity of antioxidant enzyme inhibition in skeletal muscle to reactive nitrogen species donors. Biochem Biophys Res Commun 2002; 294: 1093-1100.

109. Moncada S, Higgs A. The L-arginine-nitric oxide pathway. N Engl J Med 1993; 329: 2002-2012.

110. Jung F, Palmer LA, Zhou N, Johns RA. Hypoxic regulation of inducible nitric oxide synthase via hypoxia inducible factor-1 in cardiac myocytes. Circ Res 2000; 86: 319-325.

111. Gari PG, Morla M, Sauleda J, Agusti AG. Upregulation of the inducible form of the nitric oxide synthase and nitrotyrosine formation in skeletal muscle of COPD patients with cachexia. Eur Respir $J$ 2002; 20: Suppl. 38, 1401s.

112. Barreiro E, Comtois AS, Gea J, Laubach VE, Hussain SNA. Protein tyrosine nitration in the ventilatory muscles: role of nitric oxide synthases. Am J Respir Cell Mol Biol 2002; 26: 438-446.

113. Beckman JS, Koppenol WH. Nitric oxide, superoxide, and peroxynitrite: the good, the bad, and ugly. Am J Physiol 1996; 271: C1424-1437.

114. Demaree SR, Lawler JM, Allen MR, Bloomfield SA. Alterations in antioxidant status in the rat soleus with hindlimb suspension. Med Sci Sports Exerc 2000; 32: S104.

115. Lawler JM, Powers SK, Visser T, Van Dijk H, Kordus MJ, Ji LL. Acute exercise and skeletal muscle antioxidant and metabolic enzymes: effects of fiber type and age. Am J Physiol 1993; 265: R1344-1350.

116. Reid MB. Reactive oxygen and nitric oxide in skeletal muscle. News Physiol Sci 2001; 11: 114-119.

117. Callahan LA, Stofan DA, Szweda LI, Nethery DE, Supinski GS. Free radicals alter maximal diaphragmatic mitochondrial oxygen consumption in endotoxin-induced sepsis. Free Radic Biol Med 2001; 30: 129-138.

118. Berton E, Antonucci R, Palange P, et al. Skeletal muscle dysfunction in chronic obstructive pulmonary disease. Ventilatory function and chronic mucus hypersecretion as predictors of death from lung cancer. Monaldi Arch Chest Dis 2001; 56: 418-422.

119. Dean RT, Fu S, Stocker R, Davies MJ. Biochemistry and pathology of radical-mediated protein oxidation. Biochem $J$ 1997; 324: 1-18.

120. Bross R, Javanbakht M, Bhasin S. Anabolic interventions for aging-associated sarcopenia. J Clin Endocrinol Metab 1999; 84: 3420-3430.

121. Woods K, Marrone A, Smith J. Programmed cell death and senescence in skeletal muscle stem cells. Ann N Y Acad Sci 2000; 908: 331-335.

122. Stangel M, Zettl UK, Mix E, et al. $\mathrm{H}_{2} \mathrm{O}_{2}$ and nitric oxidemediated oxidative stress induce apoptosis in rat skeletal muscle myoblasts. J Neuropathol Exp Neurol 1996; 55: 36-43.

123. Allen DL, Linderman JK, Roy RR, et al. Apoptosis: a mechanism contributing to remodeling of skeletal muscle in response to hindlimb unweighting. Am J Physiol 1997; 273: C579-587.

124. Vescovo G, Volterrani M, Zennaro R, et al. Apoptosis in the skeletal muscle of patients with heart failure: investigation of clinical and biochemical changes. Heart 2000; 84: 431-437.

125. Gosker HR, Wouters EF, van der Vusse GJ, Schols AM. Skeletal muscle dysfunction in chronic obstructive pulmonary disease and chronic heart failure: underlying mechanisms and therapy perspectives. Am J Clin Nutr 2000; 71: 1033-1047.

126. Green DR, Reed JC. Mitochondria and apoptosis. Science 1998; 281: 1309-1312.

127. Petrache I, Otterbein LE, Alam J, Wiegand GW, Choi AM. Heme oxygenase-1 inhibits TNF-alpha-induced apoptosis in cultured fibroblasts. Am J Physiol Lung Cell Mol Physiol 2000; 278: L312-319.

128. Gea J, Orozco Levi M, Barreiro E, Ferrer A, Broquetas J. Structural and functional changes in the skeletal muscles of COPD patients: the "compartments" theory. Monaldi Arch Chest Dis 2001; 56: 214-224.

129. Kobzik L, Reid MB, Bredt DS, Stamler JS. Nitric oxide in skeletal muscle. Nature 1994; 372: 546-548.

130. Heunks LM, Dekhuijzen PN. Respiratory muscle function and free radicals: from cell to COPD. Thorax 2000; 55: 704 716.

131. Jackson MJ. Exercise and oxygen radical production by muscle. In: Sen KC, Packer L, Hanninen O, eds. Exercise and oxygen toxicity. Amsterdam, Elsevier Science, 1994; pp. $89-126$.

132. Peter D, Imre S, Mechler F. Lipid peroxidation and superoxide dismutase activity in muscle and erythrocytes in adult muscular dystrophies and neurogenic atrophies. Eur Arch Psychiatry Neurol Sci 1989; 238: 175-177.

133. Giuliani A, Cestaro B. Exercise, free radical generation and vitamins. Eur J Cancer Prev 1997; 6: Suppl. 1, S55-67.

134. Vina J, Servera E, Asensi M, et al. Exercise causes blood glutathione oxidation in chronic obstructive pulmonary disease: prevention by $\mathrm{O}_{2}$ therapy. J Appl Physiol 1996; 81: 2198-2202.

135. Heunks LMA, Vina J, Dekhuijzen PNR, et al. Exercise causes lipid peroxidation in patients with COPD. Am J Respir Crit Care Med 1998; 157: A262.

136. Lawler JM, Cline CC, Hu Z, Coast JR. Effect of oxidative stress and acidosis on diaphragm contractile function. $\mathrm{Am}$ J Physiol 1997; 273: R630-636.

137. Aghdasi B, Reid MB, Hamilton SL. Nitric oxide protects the skeletal muscle $\mathrm{Ca}^{2+}$ release channel from oxidation induced activation. J Biol Chem 1997; 272: 25462-25467.

138. Andrade FH, Reid MB, Allen DG, Westerblad H. Effect of hydrogen peroxide and dithiothreitol on contractile function of single skeletal muscle fibres from the mouse. J Physiol 1998; 509: 565-575.

139. Supinski G, Nethery D, Stofan D, Hirschfield W, DiMarco A. Diaphragmatic lipid peroxidation in chronically loaded rats. J Appl Physiol 1999; 86: 651-658.

140. Heunks LM, Bast A, van Herwaarden CL, Haenen GR, Dekhuijzen PN. Effects of emphysema and training on glutathione oxidation in the hamster diaphragm. $J \mathrm{Appl}$ Physiol 2000; 88: 2054-2061.

141. Barclay JK, Hansel M. Free radicals may contribute to oxidative skeletal muscle fatigue. Can J Physiol Pharmacol 1991; 69: 279-284.

142. Reid MB, Stokic DS, Koch SM, Khawli FA, Leis AA. $\mathrm{N}$-acetylcysteine inhibits muscle fatigue in humans. $J$ Clin Invest 1994; 94: 2468-2474.

143. Brotto MA, Nosek TM. Hydrogen peroxide disrupts $\mathrm{Ca}^{2+}$ release from the sarcoplasmic reticulum of rat skeletal muscle fibers. J Appl Physiol 1996; 81: 731-737.

144. Andersson U, Leighton B, Young ME, Blomstrand E, Newsholme EA. Inactivation of aconitase and oxoglutarate dehydrogenase in skeletal muscle in vitro by superoxide anions and/or nitric oxide. Biochem Biophys Res Commun 1998; 249: 512-516.

145. Corretti MC, Koretsune Y, Kusuoka H, Chacko VP, Zweier JL, Marban E. Glycolytic inhibition and calcium overload as consequences of exogenously generated free radicals in rabbit hearts. J Clin Invest 1991; 88: 1014-1025.

146. Rahman I. Oxidative stress, transcription factors and chromatin remodelling in lung inflammation. Biochem Pharmacol 2002; 64: 935-942.

147. Kilbourn RG, Gross SS, Jubran A, et al. NG-methyl-Larginine inhibits tumor necrosis factor-induced hypotension: implications for the involvement of nitric oxide. Proc Natl Acad Sci USA 1990; 87: 3629-3632.

148. Schulze Osthoff K, Beyaert R, Vandevoorde V, Haegeman $\mathrm{G}$, Fiers W. Depletion of the mitochondrial electron 
transport abrogates the cytotoxic and gene-inductive effects of TNF. EMBO J 1993; 12: 3095-3104.

149. Rahman I, MacNee W. Role of transcription factors in inflammatory lung diseases. Thorax 1998; 53: 601-612.

150. Guyton KZ, Liu Y, Gorospe M, Xu Q, Holbrook NJ. Activation of mitogen-activated protein kinase by $\mathrm{H}_{2} \mathrm{O}_{2}$. Role in cell survival following oxidant injury. $J$ Biol Chem 1996; 271: 4138-4142.

151. Driscoll KE. TNFalpha and MIP-2: role in particle-induced inflammation and regulation by oxidative stress. Toxicol Lett 2000; 112-113: 177-183.

152. Wong GH, Elwell JH, Oberley LW, Goeddel DV. Manganous superoxide dismutase is essential for cellular resistance to cytotoxicity of tumor necrosis factor. Cell 1989; 58: 923-931.

153. Houglum K, Filip M, Witztum JL, Chojkier M. Malondialdehyde and 4-hydroxynonenal protein adducts in plasma and liver of rats with iron overload. J Clin Invest 1990; 86: 1991-1998.

154. Holvoet P, Perez G, Zhao Z, Brouwers E, Bernar H, Collen D. Malondialdehyde-modified low density lipoproteins in patients with atherosclerotic disease. J Clin Invest 1995; 95: 2611-2619.

155. Chaudhary AK, Nokubo M, Reddy GR, et al. Detection of endogenous malondialdehyde-deoxyguanosine adducts in human liver. Science 1994; 265: 1580-1582.

156. Sridhar MK, Carter R, Lean ME, Banham SW. Resting energy expenditure and nutritional state of patients with increased oxygen cost of breathing due to emphysema, scoliosis and thoracoplasty. Thorax 1994; 49: 781-785.

157. Schols AM, Buurman WA, Staal van den Brekel AJ, Dentener MA, Wouters EF. Evidence for a relation between metabolic derangements and increased levels of inflammatory mediators in a subgroup of patients with chronic obstructive pulmonary disease. Thorax 1996; 51: 819-824.

158. Kirchberger M. Excitation and contraction of skeletal muscle. In: West JB, ed. Physiological basis of medical practice. Baltimore, Williams \& Wilkins, 1991; pp. 66-102.

159. Li YP, Schwartz RJ, Waddell ID, Holloway BR, Reid MB. Skeletal muscle myocytes undergo protein loss and reactive oxygen-mediated NF-kappaB activation in response to tumor necrosis factor alpha. FASEB J 1998; 12: 871-880.

160. Guttridge DC, Mayo MW, Madrid LV, Wang CY, Baldwin AS Jr. NF-kappaB-induced loss of MyoD messenger RNA: possible role in muscle decay and cachexia. Science 2000; 289: 2363-2366.

161. Langen RC, Schols AM, Kelders MC, Wouters EF, Janssen Heininger YM. Inflammatory cytokines inhibit myogenic differentiation through activation of nuclear factor-kappaB. FASEB J 2001; 15: 1169-1180.

162. Nomura A, Stemmermann GN, Chyou PH, Marcus EB, Buist AS. Prospective study of pulmonary function and lung cancer. Am Rev Respir Dis 1991; 144: 307-311.

163. Lange P, Nyboe J, Appleyard M, Jensen G, Schnohr P. Ventilatory function and chronic mucus hypersecretion as predictors of death from lung cancer. Am Rev Respir Dis 1990; 141: 613-617.

164. Congleton J, Muers MF. The incidence of airflow obstruction in bronchial carcinoma, its relation to breathlessness, and response to bronchodilator therapy. Respir Med 1995; 89: 291-296.

165. Vilkman S, Tuuponen T. Survival and cause of death among elderly chronic obstructive disease patients after first admission to hospital. Respiration 1997; 64: 281-284.

166. Davis AL. Bronchogenic carcinoma in chronic obstructive pulmonary disease. JAMA 1976; 235: 621-622.

167. Skillrud DM, Offord KP, Miller RD. Higher risk of lung cancer in chronic obstructive pulmonary disease. A prospective, matched, controlled study. Ann Intern Med 1986; 105: 503-507.

168. Tockman MS, Anthonisen NR, Wright EC, Donithan MG.
Airways obstruction and the risk for lung cancer. Ann Intern Med 1987; 106: 512-518.

169. Kuller LH, Ockene J, Meilahn E, Svendsen KH. Relation of forced expiratory volume in one second (FEV1) to lung cancer mortality in the Multiple Risk Factor Intervention Trial (MRFIT). Am J Epidemiol 1990; 132: 265-274.

170. Peto R, Speizer FE, Cochrane AL, et al. The relevance in adults of air-flow obstruction, but not of mucus hypersecretion, to mortality from chronic lung disease. Results from 20 years of prospective observation. Am Rev Respir Dis 1983; 128: 491-500.

171. Radzikowska E, Oniszh K, Polubiec M, Piasecki Z. Coexistence of obstructive lung diseases and lung cancer. Pneumonol Alergol Pol 1998; 66: 66-72.

172. Skillrud DM. COPD: causes, treatment, and risk for lung cancer. Compr Ther 1986; 12: 13-16.

173. Wilcock A, Crosby V, Hughes A, Fielding K, Corcoran R, Tattersfield AE. Descriptors of breathlessness in patients with cancer and other cardiorespiratory diseases. J Pain Symptom Manage 2002; 23: 182-189.

174. Cohen BH. Chronic obstructive pulmonary disease: a challenge in genetic epidemiology. Am J Epidemiol 1980; 112: 274-288.

175. Bartsch H, Nair J. Potential role of lipid peroxidation derived DNA damage in human colon carcinogenesis: studies on exocyclic base adducts as stable oxidative stress markers. Cancer Detect Prev 2002; 26: 308-312.

176. Lourenco RV, Klimek MF, Borowski CJ. Deposition and clearance of 2 micron particles in the tracheobronchial tree of normal subjects-smokers and nonsmokers. J Clin Invest 1971; 50: 1411-1420.

177. Lourenco RV, Loddenkemper R, Carton RW. Patterns of distribution and clearance of aerosols in patients with bronchiectasis. Am Rev Respir Dis 1972; 106: 857-866.

178. Foster WM, Langenback E, Bergofsky EH. Measurement of tracheal and bronchial mucus velocities in man: relation to lung clearance. J Appl Physiol 1980; 48: 965-971.

179. Beaty TH, Cohen BH, Newill CA, Menkes HA, Diamond EL, Chen CJ. Impaired pulmonary function as a risk factor for mortality. Am J Epidemiol 1982; 116: 102-113.

180. Menkes HA, Beaty TH, Cohen BH, Weinmann G. Nitrogen washout and mortality. Am Rev Respir Dis 1985; 132: $115-119$.

181. Krzyzanowski M, Wysocki M. The relation of thirteenyear mortality to ventilatory impairment and other respiratory symptoms: the Cracow Study. Int J Epidemiol 1986; 15: $56-64$.

182. Olofson J, Skoogh BE, Bake B, Svardsudd K. Mortality related to smoking habits, respiratory symptoms and lung function. Eur J Respir Dis 1987; 71: 69-76.

183. Ebi Kryston KL. Respiratory symptoms and pulmonary function as predictors of 10-year mortality from respiratory disease, cardiovascular disease, and all causes in the Whitehall Study. J Clin Epidemiol 1988; 41: 251-260.

184. Cullen K, Stenhouse NS, Wearne KL, Welborn TA. Multiple regression analysis of risk factors for cardiovascular disease and cancer mortality in Busselton, Western Australia 13-year study. J Chronic Dis 1983; 36: 371-377.

185. Tibblin G, Wilhelmsen L, Werko L. Risk factors for myocardial infarction and death due to ischemic heart disease and other causes. Am J Cardiol 1975; 35: 514-522.

186. Friedman GD, Klatsky AL, Siegelaub AB. Lung function and risk of myocardial infarction and sudden cardiac death. N Engl J Med 1976; 294: 1071-1075.

187. Cohen BH, Diamond EL, Graves CG, et al. A common familial component in lung cancer and chronic obstructive pulmonary disease. Lancet 1977; 2: 523-526.

188. Fitzpatrick FA. Inflammation, carcinogenesis and cancer. Int Immunopharmacol 2001; 1: 1651-1667.

189. Vesterinen E, Pukkala E, Timonen T, Aromaa A. Cancer incidence among 78,000 asthmatic patients. Int $J$ Epidemiol 1993; 22: 976-982. 
190. Huovinen E, Kaprio J, Vesterinen E, Koskenvuo M. Mortality of adults with asthma: a prospective cohort study. Thorax 1997; 52: 49-54.

191. Alavanja MC, Brownson RC, Boice JD Jr, Hock E. Preexisting lung disease and lung cancer among nonsmoking women. Am J Epidemiol 1992; 136: 623-632.

192. Wu AH, Fontham ET, Reynolds P, et al. Previous lung disease and risk of lung cancer among lifetime nonsmoking women in the United States. Am J Epidemiol 1995; 141: 1023-1032.

193. Weitberg AB, Weitzman SA, Clark EP, Stossel TP. Effects of antioxidants on oxidant-induced sister chromatid exchange formation. J Clin Invest 1985; 75: 1835-1841.

194. Weitzman SA, Weitberg AB, Clark EP, Stossel TP. Phagocytes as carcinogens: malignant transformation produced by human neutrophils. Science 1985; 227: 1231-1233.

195. Frenkel K, Chrzan K. Hydrogen peroxide formation and DNA base modification by tumor promoter-activated polymorphonuclear leukocytes. Carcinogenesis 1987; 8: 455-460.

196. Jackson JH, Gajewski E, Schraufstatter IU, et al. Damage to the bases in DNA induced by stimulated human neutrophils. J Clin Invest 1989; 84: 1644-1649.

197. Dizdaroglu M, Olinski R, Doroshow JH, Akman SA. Modification of DNA bases in chromatin of intact target human cells by activated human polymorphonuclear leukocytes. Cancer Res 1993; 53: 1269-1272.

198. Chong YC, Heppner GH, Paul LA, Fulton AM. Macrophage-mediated induction of DNA strand breaks in target tumor cells. Cancer Res 1989; 49: 6652-6657.

199. Schraufstatter I, Hyslop PA, Jackson JH, Cochrane CG. Oxidant-induced DNA damage of target cells. J Clin Invest 1988; 82: 1040-1050.

200. Cerutti PA. Oxy-radicals and cancer. Lancet 1994; 344: 862863.

201. Kasai H, Crain PF, Kuchino Y, Nishimura S, Ootsuyama A, Tanooka H. Formation of 8-hydroxyguanine moiety in cellular DNA by agents producing oxygen radicals and evidence for its repair. Carcinogenesis 1986; 7: 1849-1851.

202. Olson MJ. DNA strand breaks induced by hydrogen peroxide in isolated rat hepatocytes. $J$ Toxicol Environ Health 1988; 23: 407-423.

203. Beehler BC, Przybyszewski J, Box HB, Kulesz Martin MF. Formation of 8-hydroxydeoxyguanosine within DNA of mouse keratinocytes exposed in culture to UVB and $\mathrm{H}_{2} \mathrm{O}_{2}$ Carcinogenesis 1992; 13: 2003-2007.

204. Huang RP, Peng A, Hossain MZ, Fan Y, Jagdale A, Boynton AL. Tumor promotion by hydrogen peroxide in rat liver epithelial cells. Carcinogenesis 1999; 20: 485-492.

205. Wink DA, Kasprzak KS, Maragos CM, et al. DNA deaminating ability and genotoxicity of nitric oxide and its progenitors. Science 1991; 254: 1001-1003.

206. Grishko VI, Druzhyna N, LeDoux SP, Wilson GL. Nitric oxide-induced damage to mtDNA and its subsequent repair. Nucleic Acids Res 1999; 27: 4510-4516.

207. Burney S, Caulfield JL, Niles JC, Wishnok JS, Tannenbaum SR. The chemistry of DNA damage from nitric oxide and peroxynitrite. Mutat Res 1999; 424: 37-49.

208. Felley Bosco E. Role of nitric oxide in genotoxicity: implication for carcinogenesis. Cancer Metastasis Rev 1998; 17: $25-37$.

209. Stone K, Uzieblo A, Marnett LJ. Studies of the reaction of malondialdehyde with cytosine nucleosides. Chem Res Toxicol 1990; 3: 467-472.

210. Marnett LJ. Lipid peroxidation-DNA damage by malondialdehyde. Mutat Res 1999; 424: 83-95.

211. Douki T, Ames BN. An HPLC-EC assay for 1,N2-propano adducts of 2'-deoxyguanosine with 4-hydroxynonenal and other alpha,beta-unsaturated aldehydes. Chem Res Toxicol 1994; 7: 511-518.

212. Ji C, Rouzer CA, Marnett LJ, Pietenpol JA. Induction of cell cycle arrest by the endogenous product of lipid peroxidation, malondialdehyde. Carcinogenesis 1998; 19: 1275-1283.
213. Lee SH, Rindgen D, Bible RH Jr, Hajdu E, Blair IA Characterization of $2^{\prime}$-deoxyadenosine adducts derived from 4-oxo-2-nonenal, a novel product of lipid peroxidation. Chem Res Toxicol 2000; 13: 565-574.

214. Nishikawa A, Furukawa F, Kasahara K, et al. Trans-4hydroxy-2-nonenal, an aldehydic lipid peroxidation product, lacks genotoxicity in lacI transgenic mice. Cancer Lett 2000 ; 148: 81-86.

215. Chung FL, Nath RG, Ocando J, Nishikawa A, Zhang L. Deoxyguanosine adducts of t-4-hydroxy-2-nonenal are endogenous DNA lesions in rodents and humans: detection and potential sources. Cancer Res 2000; 60: 1507-1511.

216. Spencer JP, Jenner A, Chimel K, et al. DNA strand breakage and base modification induced by hydrogen peroxide treatment of human respiratory tract epithelial cells. FEBS Lett 1995; 374: 233-236.

217. Kamp DW, Dunn MM, Sbalchiero JS, Knap AM, Weitzman SA. Contrasting effects of alveolar macrophages and neutrophils on asbestos-induced pulmonary epithelial cell injury. Am J Physiol 1994; 266: L84-91.

218. Haugen TS, Skjonsberg OH, Kahler H, Lyberg T. Production of oxidants in alveolar macrophages and blood leukocytes. Eur Respir J 1999; 14: 1100-1105.

219. Prahalad AK, Soukup JM, Inmon J, et al. Ambient air particles: effects on cellular oxidant radical generation in relation to particulate elemental chemistry. Toxicol Appl Pharmacol 1999; 158: 81-91.

220. Galaris D, Evangelou A. The role of oxidative stress in mechanisms of metal-induced carcinogenesis. Crit Rev Oncol Hematol 2002; 42: 93-103.

221. Burcham PC. Genotoxic lipid peroxidation products: their DNA damaging properties and role in formation of endogenous DNA adducts. Mutagenesis 1998; 13: 287-305.

222. Du MQ, Carmichael PL, Phillips DH. Induction of activating mutations in the human c-Ha-ras-1 proto-oncogene by oxygen free radicals. Mol Carcinog 1994; 11: 170-175.

223. Feig DI, Reid TM, Loeb LA. Reactive oxygen species in tumorigenesis. Cancer Res 1994; 54: 1890s-1894s.

224. Cerda S, Weitzman SA. Influence of oxygen radical injury on DNA methylation. Mutat Res 1997; 386: 141-152.

225. Ghosh R, Mitchell DL. Effect of oxidative DNA damage in promoter elements on transcription factor binding. Nucleic Acids Res 1999; 27: 3213-3218.

226. Trush MA, Seed JL, Kensler TW. Oxidant-dependent metabolic activation of polycyclic aromatic hydrocarbons by phorbol ester-stimulated human polymorphonuclear leukocytes: possible link between inflammation and cancer. Proc Natl Acad Sci USA 1985; 82: 5194-5198.

227. Kensler TW, Egner PA, Moore KG, Taffe BG, Twerdok LE, Trush MA. Role of inflammatory cells in the metabolic activation of polycyclic aromatic hydrocarbons in mouse skin. Toxicol Appl Pharmacol 1987; 90: 337-346.

228. Cavalieri EL, Rogan EG, Cremonesi P, Devanesan PD Radical cations as precursors in the metabolic formation of quinones from benzo[a]pyrene and 6-fluorobenzo[a]pyrene. Fluoro substitution as a probe for one-electron oxidation in aromatic substrates. Biochem Pharmacol 1988; 37: 2173-2182.

229. Bodell WJ, Devanesan PD, Rogan EG, Cavalieri EL. 32Ppostlabeling analysis of benzo[a]pyrene-DNA adducts formed in vitro and in vivo. Chem Res Toxicol 1989; 2: $312-315$.

230. Rogan EG, RamaKrishna NV, Higginbotham S, et al. Identification and quantitation of 7-(benzo[a]pyren-6-yl)guanine in the urine and feces of rats treated with benzo[a]pyrene. Chem Res Toxicol 1990; 3: 441-444.

231. Wang IY, Rasmussen RE, Crocker TT. Metabolism of benzo(a)pyrene by microsomes from tissues of pregnant and fetal hamsters. Life Sci 1974; 15: 1291-1300.

232. Davies KJ. The broad spectrum of responses to oxidants in proliferating cells: a new paradigm for oxidative stress. IUBMB Life 1999; 48: 41-47. 
233. Petruska JM, Mosebrook DR, Jakab GJ, Trush MA. Myeloperoxidase-enhanced formation of (+-)-trans-7,8dihydroxy-7,8-dihydrobenzo[a]pyrene-DNA adducts in lung tissue in vitro: a role of pulmonary inflammation in the bioactivation of a procarcinogen. Carcinogenesis 1992; 13: 1075-1081.

234. Gruss T, Fabian I. Ascorbic acid protects from activation of multiple caspases and of cytochrome c release induced by oxidative stress in human leukemia cells. Exper Hematol 2000; 28: 34.

235. Barnes PJ. New therapies for chronic obstructive pulmonary disease. Thorax 1998; 53: 137-147.

236. Grandjean EM, Berthet P, Ruffmann R, Leuenberger P,
Berthet PH. Efficacy of oral long-term $N$-acetylcysteine in chronic bronchopulmonary disease: a meta-analysis of published double-blind, placebo-controlled clinical trials. Clin Ther 2000; 22: 209-221.

237. Bast A. Antioxidant pharmacotherapy. Drug News and Perspectives 1994; 7: 465-472.

238. Cross CF, vander Vliet A, O'Neill CA, Louie S, Halliwell B. Oxidants, antioixidants, and respiratory tract lining fluids. Environ Health Perspect 1994; 102: 185-191.

239. Biewenga GP, Veening-Griffioen DH, Nicastia AJ, Haenen GRMM, Bast A. A new antioxidant property of dihydrolipoic acid: repair of oxidatively damaged alpha-1antiprotease. Drug Res 1998; 48: 144-148. 